Volume 95 of the Yale Series of Younger Poets 


\title{
Maurice Manning
}

Foreword by W. S. Merwin

\author{
Yale University Press
}

New Haven and London 
Copyright ( $\odot 2001$ by Yale University.

"Ace" and "Reserve" originally appeared in Green Mountains Review.

"Analog" originally appeared in The New Yorker.

"Eclipse" originally appeared in Hayden's Ferry Review.

"Raptor," "Affirmation," and "Canis Apologetica” originally appeared in The Spoon River Poetry Review.

All rights reserved. This book may not be reproduced, in whole or in part, including illustrations, in any form (beyond that copying permitted by Sections 107 and 108 of the U.S. Copyright Law and except by reviewers for the public press), without written permission from the publishers.

Designed by Nancy Ovedovitz and set in Postscript Century Expanded type by The Composing Room of Michigan, Inc. Printed in the United States of America by Vail-Ballou Press, Binghamton, New York.

Library of Congress Cataloging-in-Publication Data Manning, Maurice, 1966-

Lawrence Booth's book of visions / Maurice Manning.

p. cm. - (Yale series of younger poets ; v. 95)

ISBN 0-300-08996-1 (alk. paper) — ISBN 0-300-08998-8 (pbk. : alk. paper)

I. Title. II. Series.

PS3613.A36 L39 2001

811'.6-dc21 2001000806

A catalogue record for this book is available from the British Library.

The paper in this book meets the guidelines for permanence and durability of the Committee on Production Guidelines for Book Longevity of the Council on Library Resources.

$\begin{array}{llllllllll}10 & 9 & 8 & 7 & 6 & 5 & 4 & 3 & 2 & 1\end{array}$ 
This book is dedicated to:

WDC and JYH

HEROES

and

Hank, Hoyt, Cobb, Gangey, The Parson, and Rev. Andre Crabtree SAINTS OF THE MIDNIGHT CHOIR 
Ayre Rectified. With a Digression of the Ayre.

As a long-winged Hawke when hee is first whistled off the fist, mounts aloft, and for his pleasure fetcheth many a circuit in the Ayre, still soaring higher and higher, till hee bee come to his full pitch; and in the end when the game is sprung, comes downe amaine, and stoopes upon a sudden: so will I, having now come at last into these ample fields of Ayre, wherein I may freely expatiate and exercise my selfe, for my recreation a while rove, wander round about the world, mount aloft to those aethereall orbes and celestiall spheres, and so descend to my former elements againe.

Robert Burton, The Anatomy of Melancholy, 1632 